\title{
Amphibian decline and extinction: What we know and what we need to learn
}

\author{
James P. Collins* \\ School of Life Sciences, Arizona State University, Tempe, Arizona 85287-4501, USA
}

\begin{abstract}
For over 350 million yr, thousands of amphibian species have lived on Earth. Since the 1980s, amphibians have been disappearing at an alarming rate, in many cases quite suddenly. What is causing these declines and extinctions? In the modern era (post 1500) there are 6 leading causes of biodiversity loss in general, and all of these acting alone or together are responsible for modern amphibian declines: commercial use; introduced/exotic species that compete with, prey on, and parasitize native frogs and salamanders; land use change; contaminants; climate change; and infectious disease. The first 3 causes are historical in the sense that they have been operating for hundreds of years, although the rate of change due to each accelerated greatly after about the mid-20th century. Contaminants, climate change, and emerging infectious diseases are modern causes suspected of being responsible for the so-called 'enigmatic decline' of amphibians in protected areas. Introduced/exotic pathogens, land use change, and infectious disease are the 3 causes with a clear role in amphibian decline as well as extinction; thus far, the other 3 causes are only implicated in decline and not extinction. The present work is a review of the 6 causes with a focus on pathogens and suggested areas where new research is needed. Batrachochytrium dendrobatidis $(B d)$ is a chytrid fungus that is an emerging infectious disease causing amphibian population decline and species extinction. Historically, pathogens have not been seen as a major cause of extinction, but $B d$ is an exception, which is why it is such an interesting, important pathogen to understand. The late 20th and early 21st century global biodiversity loss is characterized as a sixth extinction event. Amphibians are a striking example of these losses as they disappear at a rate that greatly exceeds historical levels. Consequently, modern amphibian decline and extinction is a lens through which we can view the larger story of biodiversity loss and its consequences.
\end{abstract}

KEY WORDS: Amphibian · Extinction · Decline $\cdot$ Chytrid fungus $\cdot$ Pathogens $\cdot$ Biodiversity loss

\section{INTRODUCTION}

Extinction has been a common event throughout Earth's history. Some $99 \%$ of the species that have been on the planet are now extinct (Raup 1991). Extinction is typically thought of as falling into the realm of paleontological research - a distant and remote process. However, throughout the 20th century increasingly well studied populations of plants and animals revealed how species undergo increases and decreases in population sizes sometimes even to local extinction. During the last $50 \mathrm{yr}$, researchers studying modern ecosystems have confronted species extinction at local and global scales more and more frequently.
Understanding the consequences of biodiversity loss is one of the grand challenge research areas in biology.

We are the first generation of scientists with the tools to address the dimensions of biodiversity on Earth, and ironically we may be the last generation with the opportunity to discover and understand Earth's extant species before many are lost. Thomas et al. (2004, p. 145) predicted that 'on the basis of mid-range climate-warming scenarios for 2050 , that $15-37 \%$ of species' in their sample of regions and taxa will be 'committed to extinction.'

The rapidity with which many ecological and evolutionary processes are now changing means that more than ever before we must understand the consequences of species losses. In addition to efforts to con- 
serve species, we also need research on the biology of extinction. These research programs would include the theoretical, modeling, and empirical studies required to predict how ecosystems will change in the near and long term as biodiversity is lost. At the start of the 21st century, there are unfortunately several candidate groups for model organisms and systems that would inform such studies, especially among vertebrates: about $2 \%$ of bird species, $4 \%$ of mammal species, and $7 \%$ of amphibian species are critically endangered (Stuart et al. 2004), and the number of endangered vertebrate species has been increasing (Hoffmann et al. 2010). In particular, for amphibians the recent extinction rate is about 200 times the historical background rate (McCallum 2007, Roelants et al. 2007). Amphibians are among a number of groups providing evidence that we are likely in the midst of a sixth mass extinction (Wake \& Vredenburg 2008).

There are 6 major causes of modern amphibian declines and extinctions: commercial use; introduced/ exotic species that prey on, compete with, and parasitize native frogs and salamanders; land use change; contaminants; climate change; and infectious disease (Collins \& Crump 2009). The present work briefly summarises what we know about each cause, with suggestions about major areas for research.

\section{COMMERCIAL USE}

A 2001 UN/FAO report (Teixeira et al. 2001) reached 4 main conclusions:

(1) Almost $95 \%$ of the world demand for frog legs and frog products is still supplied from wild stocks;

(2) In 1998, the international trade in frog legs involved more than 30 countries with a value of around US \$49 million;

(3) The main focus of harvesting is 11 species worldwide;

(4) Worldwide from 1987 to 1997, an average of about 4716 metric tons of frogs were collected annually - and these data do not include the major exporting nations of China and Vietnam.

US trade records from 1998 to 2002 reinforce these conclusions: 5.2 million $\mathrm{kg}$ and 15 million individuals were imported and declared as wild caught; $96 \%$ of the trade was commercial, mainly for pets and food; most trade involved 9 frog families and 2 salamander families (Schlaepfer et al. 2005). Schlaepfer et al. (2005, p. 263) concluded that the data 'do not provide conclusive evidence of widespread, unsustainable collections. They [the data] do, however, reveal that the volume of animals taken from the wild (for the US market alone, let alone globally) is large enough to potentially extirpate populations or species.'
It is important to realize that beyond diminishing the population size of native species, commercially traded amphibians can also negatively affect animals distantly removed from source populations. In the western USA, Ambystoma tigrinum virus (ATV) and the amphibian chytrid fungus Batrachochytrium dendrobatidis $(B d)$ are spread via the bait trade in tiger salamanders Ambystoma tigrinum (Picco \& Collins 2008). Schloegel et al. (2009) reported that 28 million Rana catesbeiana (=Lithobates catesbeianus; American bullfrog, following Frost et al. 2006) were imported into 3 US markets (Los Angeles, San Francisco, and New York) from 2000 to 2005. The overall infection prevalence was $62 \%$ (306/493) for $B d$ and $8.5 \%$ (50/588) for ranaviruses.

Both studies implicate commercially traded amphibians as a source of pathogen pollution. Despite accumulating evidence that commercial trade causes declines and moves pathogens that may infect native species, we have no example yet where commerce alone has decreased amphibian population sizes to extinction. But the potential is there. Fisher \& Garner (2007) reported that 28 species of introduced frogs and salamanders carried $B d$, which is widely implicated in amphibian decline and extinction, as documented by other papers in this Special Issue. Schloegel et al. (2010) found that $5 \mathrm{Bd}$ isolates from Brazilian bullfrog farms grouped closely with each other and with isolates from other sites in Latin America, and their results led them to conclude that 'The striking similarity in captive bullfrog, wild bullfrog and wild, native frog isolates from Latin America suggests that there is, or has been, transmission among these populations and/or that the infections stem from a common source population' (p. 56). Gratwicke et al. (2010) reinforce the role of the international trade in amphibians as a source of pathogen pollution.

Here are 4 leading questions that need answers: When is commercial collecting a threat to population survival? Has commercial collecting caused species extinction directly by reduced population size or indirectly by pathogen pollution, introgression, or introduction of exotic species? Can commercial collecting be an effective conservation tool, for example, as a basis for eco-tourism or sustainable harvesting as a means to protect amphibians and their surrounding habitats? And can laws and regulations be put in place to manage amphibian populations sustainably?

\section{INTRODUCED SPECIES}

In habitats with exotic species, the size of native amphibian populations is often greatly reduced. Experiments show that when exotic, predatory fish and crayfish are present, native amphibians reduce activity, use different habitats, increase use of refuges, are smaller 
at metamorphosis, survive less well, show more injuries, and have fewer resources because of competition (Collins \& Crump 2009). Introduced trout and the decline of mountain yellow-legged frogs in California, USA is an especially well studied example based on many observations and experiments (Knapp et al. 2001, 2007, Carey et al. 2003, Vredenberg 2004, Knapp 2005).

Although there is ample evidence that introduced frogs, such as American bullfrogs, cause native species to decline, there is no evidence yet that an introduced amphibian species caused the extinction of a native amphibian species. Habitat change and the introduction of non-native mammals are suggested as causes of the extinction of the 3 largest New Zealand frog species (www.nzfrogs.org/NZ+Frogs/Conservation.html). It is now accepted that the introduced amphibian pathogen $B d$ can cause frog and salamander populations to decline and frog species to go extinct.

Overall, introduced species raise several key questions: Why are some species, like American bullfrogs and cane toads Bufo marinus (= Rhinella marina; marine/cane toad, following Frost et al. 2006) so successful? Has an exotic species, other than $B d$, caused extinction of an amphibian species? What is the relative importance of the various ways in which species enter new habitats? Does the success of introduced species, such as Eleutherodactylus coqui in Hawaii, offer a model for conservation by managed relocation of species (Minteer \& Collins 2010)?

\section{LAND USE CHANGE}

Sri Lanka offers a clear example of how land use change and amphibian species losses are related (Meegaskumbura et al. 2002). The country has $0.013 \%$ of the world's land surface, and $>2 \%$ percent of the world's frog species. Some $95 \%$ of its rain forests are gone; patches now cover $\sim 750 \mathrm{~km}^{2}$ or $<2 \%$ of the island (Pethiyagoda \& Manamendra-Arachchi 1998). A survey between 1993 and 2003, primarily in rain forest, revealed some 140 anuran species, including 100 new species. However, 17 of Sri Lanka's native frog species disappeared in the past decade; $50 \%$ of 34 confirmed amphibian extinctions in the past 5 centuries. About 100 species known from 19th century museum collections were not recorded in the survey and are probably extinct (Pennisi 2002).

There are numerous examples of how land use change and habitat loss cause the decline and extinction of many species, including amphibians (Collins \& Crump 2009). All evidence indicates that more losses are expected (Gallant et al. 2007). Land use change that results in habitat destruction is the leading cause of amphibian decline and extinction. This straightfor- ward and important fact must not be lost among our concerns about the role that other causes may play. It is clear that the leading question moving ahead is: What controls amphibian population sizes and species richness as land use and land cover change? What must be done to ameliorate the impact of land use change or even block land use changes that threaten amphibian habitats?

Commercial use, introduced/exotic species, and land use change are among the historical causes of amphibian declines (Collins \& Storfer 2003). These 3 causes have been acting for centuries, and all 3 apply to many species beyond amphibians. Contaminants, climate change, and emerging infectious diseases are important late 20th century causes of decline and even extinction. They are the primary hypothesized causes of the so called 'enigmatic declines' - the decline of amphibians in protected areas (Stuart et al. 2004).

\section{CONTAMINANTS}

Studies of how chemicals affect amphibians typically fit somewhere within a 3-step hierarchical research strategy (Boone \& Bridges 2003):

(1) Expose individual organisms in the laboratory to chemicals to assess basic physiological responses. Sparling (2003) reviewed $\mathrm{LD}_{50}$ values for 30 organic and inorganic amphibian contaminants in which the laboratory tests were conducted at or below concentrations reported from environmental studies. He concluded that many compounds occurred in the environment at higher than toxic concentrations.

(2) Integrate these findings with studies of individuals exposed to chemicals under diverse environmental conditions, e.g. mesocosms (Relyea et al. 2005, Kiesecker 2002, Rohr et al. 2008a) or habitats (Boone et al. 2004, McCoy et al. 2008, Rohr et al. 2008b). These studies show mixed results as far as amphibians are concerned. In some cases, pesticides have a negative effect on amphibians as predicted based on laboratory experiments. In other cases, however, the effect is positive presumably because pesticides influence one or more species in the amphibian food web in ways that positively affect frogs and salamanders.

(3) Relate the findings from approaches (1) and (2) to changes in adult population sizes of amphibians at local and regional scales. Atrazine is a widely used herbicide that causes feminization of male African clawed frogs Xenopus laevis in the laboratory (Hayes et al. 2002, 2010). Hayes et al. (2002) also examined this effect by collecting adult, wild leopard frogs at 8 sites across the USA where atrazine was used in high concentrations. At 7 of the 8 sites with high atrazine concentrations in the water, males had oocytes developing in the testes. 
Males were not hermaphrodites at sites with low atrazine levels or no agriculture. Hayes et al. (2002) concluded that atrazine was responsible for these signs of feminization. Davidson et al. (2001) reported a significant association between agricultural chemical use in California's Central Valley and declines in 4 frog species in the Sierra Nevada. These mountains and their amphibian habitats are downwind of the valley and the research team hypothesized that pesticides drifting from farms are deposited in the high elevation habitats to the detriment of their amphibian inhabitants.

The collection of frogs with developmental abnormalities in 1995 in Minnesota raised the suspicion that contaminants might be a cause (Souder 2000). Johnson et al. (1999) used Pacific tree frogs to show that a flatworm parasite (Ribieroia ondatrae) regularly causes developmental abnormalities such as those seen in the Minnesota frogs. A comprehensive analysis of amphibian developmental abnormalities led Lannoo (2008) to conclude that abnormalities like missing eyes that are inconsistent with the parasite hypothesis occur frequently in areas without trematodes. He summarized 10 natural (e.g. wounding or high tadpole densities) and 7 man-made (e.g. ionising radiation or agricultural chemicals) causes of abnormalities and concluded that trematode-induced abnormalities are a minority of cases, largely restricted to the upper Midwest and parts of California in the USA. Frogs with abnormalities occur in some Vermont ponds without Ribeiroia obdatrae (Skelly et al. 2007). Nearby agricultural areas are possible risk factors, but urban and suburban areas may be an even greater risk. Excess nitrogen is a possible cause, but other possibilities include insecticides, herbicides, or pharmaceuticals in surface water.

Two things are needed to conclude that a contaminant negatively affects a population. First, ecologically relevant concentrations of the contaminant must be a new source of population stress that results in reduced recruitment of new animals or increased loss of animals beyond that caused by other stressors. Second, decreases in population recruitment or increases in population losses must exceed those typically experienced from natural stressors such as predation, competition, or parasitism. These are tough standards to meet and they have not been met for amphibians. Indirect evidence suggests contaminants play a role in amphibian population declines. At present, we have no evidence that toxins cause extinction.

\section{CLIMATE CHANGE}

The warming of Earth's atmosphere is affecting many organisms in complex ways that vary regionally. For example:
- Glacial recession in the Peruvian Andes is creating new amphibian habitats at sites within recently deglaciated terrain above $5300 \mathrm{~m}$ (Seimon et al. 2007).

- McCaffery \& Maxell (2010) studied Columbia spotted frogs Rana luteiventris in the Bitterroot Mountains of Montana, USA. They documented an increase in survival and breeding probability as severity of winter decreased leading them to conclude that 'a warming climate with less severe winters is likely to promote population viability in this montane frog population' (p. 8644).

- At La Selva, Costa Rica, amphibian populations have declined over $35 \mathrm{yr}$ and Whitfield et al. (2007) attributed the losses to climate-driven reductions in amphibian microhabitats.

- Recent climatic warming and resultant wetland desiccation are causing declines in 4 once-common amphibian species native to Yellowstone National Park in the western USA (McMenamin et al. 2008).

Pounds et al. (2006) proposed the 'chytrid thermaloptimum hypothesis' based on a complex relationship between temperature change and improved growth of the amphibian chytrid fungus in tropical habitats. Several teams have tested features of the hypothesis and failed to confirm the details (Lips et al. 2006, 2008, Rohr et al. 2008c, Woodhams et al. 2008, Anchukaitis \& Evans 2010, Walker et al. 2010). The chytrid thermaloptimum hypothesis assumes that $B d$ is endemic in amphibian populations and changing habitat conditions trigger infectious disease emergence (Rachowicz et al. 2005). In contrast, $B d$ exhibits many of the characteristics of an invading pathogen that triggers epidemics in naïve amphibian hosts once it enters a new ecosystem (Morehouse et al. 2003, Lips et al. 2006, Morgan et al. 2007, Laurance 2008). After reviewing the literature on climate change and amphibian infectious disease, Collins \& Crump (2009, p. 173) concluded: 'The emerging endemic hypothesis is complex and requires taking mechanisms known to cause local emergence of endemic pathogens and scaling them up to regional or global levels. According to Morse [1995], this hypothesis is an unconfirmed cause of pandemics at the global scale. The chytrid thermal-optimum hypothesis is an instance of the emerging endemic hypothesis: Changing temperatures facilitate $B d$ 's growth in microhabitats. Climate warming is the environmental cue common to widely separated populations that is hypothesized to be the stimulus for pathogen emergence. UV-B radiation and global warming are the only environmental cues proposed as accounting for the worldwide population losses seen in amphibians. The novel or spreading pathogen hypothesis is the best explanation for the enigmatic decline and even extinction of frog populations across widely 
separated regions.' After $B d$ enters a system it then exhibits features of an endemic pathogen.

Climate warming's effects vary from none to positive or negative depending on the species and region. Atmospheric warming is projected far into the 21st century in the most recent Intergovernmental Panel on Climate Change (IPCC) report (IPCC 2008; see also Williams et al. 2007). How will these expected changes affect amphibians? Based on a study of climate warming's effects on range distributions of European amphibians, Araújo et al. (2006) asked several questions that apply equally well across all species: What proportion of species will lose and gain suitable climate space in the future? Do projections vary with taxonomic, spatial or environmental properties? What climate factors drive projections? And how will climate change affect extinction probabilities?

\section{INFECTIOUS DISEASES}

A diversity of micro- and macroparasites infect amphibians (Collins \& Crump 2009). Two microparasites, iridioviruses and the amphibian chytrid fungus $B d$, are emerging infectious diseases that are the focus of research relative to decline and extinction of frogs and salamanders; we know too little about caecilians, the third order of the class Amphibia, to draw meaningful conclusions about how pathogens affect these secretive, worm-like organisms.

At least 8 Ranavirus strains may infect one or more species of frogs or salamanders. Infected individuals may die quickly, remain chronically infected, or clear the virus and become reinfected. Ranaviruses cause epidemics in native frogs in Europe, South America, and Australia; in frogs and salamanders in North America; and in aquaculture colonies of frogs in Asia (Carey et al. 2003). There is no evidence that ranaviruses are causing species extinctions in frogs or salamanders. The dynamics of Ambystoma tigrinum virus and tiger salamanders Ambystoma tigrinum most closely fits a density-dependent model of host-pathogen dynamics, and under these conditions extinction is not expected (Brunner et al. 2007, Greer et al. 2008).

$B d$ differs from Ranavirus (Collins \& Crump 2009). Notably, $B d$ is associated with anuran declines as well as extinctions in Australia, Africa, Central, South, and North America, but also coexists with non-declining species. $B d$ infects most amphibian species tested with effects varying from no clinical disease to $100 \%$ mortality. Microenvironment affects host susceptibility.

The amphibian chytrid fungus meets several conditions that could result in a pathogen causing extinction; namely, some amphibian species are biotic reservoirs that carry and transmit $B d$ with seemingly no negative effects, and there is some evidence suggesting abiotic pathogen reservoirs; and $B d$ transmission occurs even at low densities, for example, during mating or when individuals congregate perhaps in response to drying conditions (Collins \& Crump 2009).

In theory, density-dependent pathogen transmission alone will not drive a host population to extinction (Kermack \& McKendrick 1927, Anderson \& May 1991), although extinction might occur if population size becomes so small that stochastic processes lead to the population's demise. Ranaviruses seem to fit this model. Populations regularly decline, even to local extinction, for example at the scale of one or a few ponds, but eventually recover. In contrast, $B d$ infected populations fit a model of density-independent host- pathogen dynamics. Extinction may result if transmission is independent of density or the pathogen has a reservoir in the environment or another species (McCallum et al. 2001, de Castro \& Bolker 2005). Sexually-transmitted diseases are common examples of such a transmission mode. (O'Keefe 2005, Ryder et al. 2005).

Several questions call for further research. What are the details surrounding how $B d$ drives species extinct? Does $B d$ have exceptional traits that make it a pathogen likely to cause extinction? What confers $B d$ resistance or tolerance in some host species: skin peptides, skin microflora, behavior, acquired immunity, variation in $B d$ pathogenicity, host genetics, or all of the above? What are the population dynamics of local and regional host-pathogen biology? Does the biology of the amphibian-chytrid association have features consistent with what we know in theory about traits of a host-pathogen system that might under some conditions cause host extinction? Will species recover after a selective sweep? What is $B d$ 's evolutionary history and where/how did $B d$ first emerge? How does/did $B d$ disperse between regions? Are there effective $B d$ mitigation strategies other than removing animals to ex situ conservation facilities?

\section{CONCLUSION}

Extinction attracts the attention of paleontologists, conservation biologists, and in the last decades of the 20th century a diversity of researchers studying contemporary ecological and evolutionary processes. Amphibians illustrate that it is possible for an infectious disease to emerge and place many species within a class of organisms at risk of extinction. Some 200 of the more than 6000 amphibian species have been tested for $B d$ susceptibility, and all were found susceptible suggesting that the entire class is at risk from this pathogen. 
Modern amphibian decline and extinction bring losses that paleontologists relegate to cataclysmic events into the realm of current ecological processes. Modeling and predicting ecosystem processes in a montane, neotropical ecosystem today means having to assume that within the foreseeable future a significant fraction of the grazers (tadpoles) and predators (metamorphosed amphibians) could be gone from the aquatic and terrestrial components of the ecosystem.

The studies reviewed here and in the other papers of this DAO Special Issue reflect advances in our understanding of the causes of amphibian population decline and extinction over the last 2 decades - but many questions still need answers.

\section{LITERATURE CITED}

Anchukaitis KJ, Evans MN (2010) Tropical cloud forest climate variability and the demise of the Monteverde golden toad. Proc Natl Acad Sci USA 107:5036-5040

Anderson RM, May RM (1991) Infectious diseases of humans: dynamics and control. Oxford University Press, Oxford

> Araújo MB, Thuiller W, Pearson RG (2006) Climate warming and the decline of amphibians and reptiles in Europe. J Biogeogr 33:1712-1728

Boone M, Bridges C (2003) A hierarchical approach in studying the effects of an insecticide on amphibians. In: Linder GL, Krest SK, Sparling DW (eds) Amphibian decline: an integrated analysis of multiple stressor effects. Society of Environmental Toxicology and Chemistry (SETAC), Pensacola, FL, p 265-270

Boone MD, Semlitsch RD, Fairchild JF, Rothermel BB (2004) Effects of an insecticide on amphibians in large-scale experimental ponds. Ecol Appl 14:685-691

Brunner JL, Schock DM, Collins JP (2007) Transmission dynamics of the amphibian ranavirus Ambystoma tigrinum virus. Dis Aquat Org 77:87-95

Carey C, Bradford DF, Brunner JL, Collins JP and others (2003) Biotic factors in amphibian population declines. In: Linder GL, Krest SK, Sparling DW (eds) Amphibian decline: an integrated analysis of multiple stressor effects. Society of Environmental Toxicology and Chemistry (SETAC), Pensacola, FL, p 153-208

Collins JP, Crump ML (2009) Extinction in our times. Global amphibian decline. Oxford University Press, Oxford

Collins JP, Storfer A (2003) GLOBAL amphibian declines: Sorting the hypotheses. Divers Distrib 9:89-98

> Davidson C, Shaffer HB, Jennings MR (2001) Declines of the California red-legged frog: Climate, UV-B, habitat, and pesticides hypotheses. Ecol Appl 11:464-479

> de Castro F, Bolker B (2005) Mechanisms of disease-induced extinction. Ecol Lett 8:117-126

> Fisher MC, Garner TWJ (2007) The relationship between the emergence of Batrachochytrium dendrobatidis, the international trade in amphibians and introduced amphibian species. Fungal Biol Rev 21:2-9

Frost DR, Grant T, Faivovich J, Bain RH and others (2006) The amphibian tree of life. Bull Am Mus Nat Hist 297:1-370

Gallant AL, Klaver RW, Casper GS, Lannoo MJ (2007) Global rates of habitat loss and implications for amphibian conservation. Copeia 2007:967-979

Gratwicke B, Evans MJ, Jenkins PT, Kusrini MD, Moore RD, Sevin J, Wildt DE (2010) Is the international frog legs trade a potential vector for deadly amphibian pathogens? Front Ecol Environ 8:438-442

Greer AL, Briggs CJ, Collins JP (2008) Testing a key assumption of host pathogen theory: Density and disease transmission. Oikos 117:1667-1673

Hayes T, Haston K, Tsui M, Hoang A, Haeffele C, Vonk A (2002) Feminization of male frogs in the wild. Nature 419:895-896

Hayes TB, Khoury V, Narayan A, Nazir M and others (2010) Atrazine induces complete feminization and chemical castration in male African clawed frogs (Xenopus laevis). Proc Natl Acad Sci USA 107:4612-4617

Hoffmann M, Hilton-Taylor C, Angulo A, Böhm M and others (2010) The impact of conservation on the status of the world's vertebrates. Science Express doi:10.1126/science. 1194442

IPCC (Intergovernmental Panel on Climate Change) (2008) IPCC Fourth Assessment Report. Climate Change 2007. Cambridge University Press, Cambridge. Available at: www.ipcc.ch

Johnson PTJ, Lunde KB, Richie EG, Launer AE (1999) The effect of trematode infection on amphibian limb development and survivorship. Science 284:802-804

Kermack WO, McKendrick AG (1927) A contribution to the mathematical theory of epidemics. Proc R Soc Lond A 115: $700-721$

> Kiesecker JM (2002) Synergism between trematode infection and pesticide exposure: a link to amphibian limb deformities in nature? Proc Natl Acad Sci USA 99:9900-9904

Knapp RA (2005) Effects of nonnative fish and habitat characteristics on lentic herpetofauna in Yosemite National Park, USA. Biol Conserv 121:265-279

Knapp RA, Matthews KR, Sarnelle O (2001) Resistance and resilience of alpine lake fauna to fish introductions. Ecol Monogr 71:401-421

- Knapp RA, Boiano DM, Vredenberg VT (2007) Removal of nonnative fish results in population expansion of a declining amphibian (mountain yellow-legged frog, Rana muscosa). Biol Conserv 135:11-20

Lannoo MJ (2008) Malformed frogs: the collapse of aquatic ecosystems. University of California Press, Berkeley, CA

Laurance WF (2008) Global warming and amphibian extinctions in eastern Australia. Anim Ecol 33:1-9

Lips KR, Brem F, Brenes R, Reeve JD and others (2006) Emerging infectious disease and the loss of biodiversity in a neotropical amphibian community. Proc Natl Acad Sci USA 103:3165-3170

Lips KR, Diffendorfer J, Mendelson JR III, Sears MW (2008) Riding the wave: reconciling the roles of disease and climate change in amphibian declines. PLoS Biol 6:e72

McCaffery RM, Maxell BA (2010) Decreased winter severity increases viability of a montane frog population. Proc Natl Acad Sci USA 107:8644-8649

> McCallum ML (2007) Amphibian decline or extinction? Current declines dwarf background extinction rate. J Herpetol 41:483-491

McCallum H, Barlow N, Hone J (2001) How should pathogen transmission be modelled? Trends Ecol Evol 16: 295-300

McCoy KA, Bortnick LJ, Campbell CM, Hamlin HJ, Guillette LJ Jr, St. Mary CM (2008) Agriculture alters gonadal form and function in the toad Bufo marinus. Environ Health Perspect 116:1526-1532

> McMenamin SK, Hadley EA, Wright CK (2008) Climate change and wetland desiccation cause amphibian decline in Yellowstone National Park. Proc Natl Acad Sci USA 105:16988-16993 
Meegaskumbura M, Bossuyt F, Pethiyagoda R, ManamendraArachchi K, Bahir M, Milinkovitch MC, Schneider CJ (2002) Sri Lanka: an amphibian hot spot. Science 298:379

Minteer BA, Collins JP (2010) Move it or lose it? The ecological ethics of relocating species under climate change. Ecol Appl 20:1801-1804

Morehouse EA, James TY, Ganley ARD, Vilgalys R, Berger L, Murphy PJ, Longcore JE (2003) Multilocus sequence typing suggests the chytrid pathogen of amphibians is a recently emerged clone. Mol Ecol 12:395-403

Morgan JAT, Vredenberg VT, Rachowicz LJ, Knapp RA and others (2007) Population genetics of the frog-killing fungus Batrachochytrium dendrobatidis. Proc Natl Acad Sci USA 104:13845-13850

Morse SS (1995) Factors in the emergence of infectious diseases. Emerg Infect Dis 1:7-15

O'Keefe KJ (2005) The evolution of virulence in pathogens with frequency-dependent transmission. J Theor Biol 233: $55-64$

Pennisi E (2002) 100 frogs a-leaping for biodiversity. Science 298:339-340

Pethiyagoda R, Manamendra-Arachchi A (1998) Evaluating Sri Lanka's amphibian diversity. Occasional Papers No. 2, Wildlife Heritage Trust. Available at www.lankalibrary. com/wlife/amphi.htm

Picco AM, Collins JP (2008) Amphibian commerce as a likely source of pathogen pollution. Conserv Biol 22:1582-1589

Pounds JA, Bustamante MR, Coloma LA, Consuegra JA and others (2006) Widespread amphibian extinctions from epidemic disease driven by global warming. Nature 439 : 161-167

Rachowicz LJ, Hero JM, Alford RA, Taylor JW and others (2005) The novel and endemic pathogen hypotheses: competing explanations for the origin of emerging diseases of wildlife. Conserv Biol 19:1441-1448

Raup DM (1991) Extinction: bad genes or bad luck. WW Norton, New York, NY

Relyea RA, Schoeppner NM, Hoverman JT (2005) Pesticides and amphibians: the importance of community context. Ecol Appl 15:1125-1134

Roelants K, Gower DJ, Wilkinson M, Loader SP and others (2007) Global patterns of diversification in the history of amphibians. Proc Natl Acad Sci USA 104:887-892

Rohr JR, Schotthoefer AM, Raffel TR, Carrick HJ and others (2008a) Agrochemicals increase trematode infections in a declining amphibian. Nature 455:1235-1239

Rohr JR, Raffel TR, Sessions SK, Hudson PJ (2008b) Understanding the net effects of pesticides on amphibian trematode infections. Ecol Appl 18:1743-1753

Rohr JR, Raffel TR, Romansic JM, McCallum H, Hudson PJ (2008c) Evaluating the links between climate, disease spread, and amphibian declines. Proc Natl Acad Sci USA 105:17436-17441

Ryder JJ, Webberley KM, Boots M, Knell RJ (2005) Measuring the transmission dynamics of a sexually transmitted disease. Proc Natl Acad Sci USA 102:15140-15143

Editorial responsibility: Cynthia Carey,

Boulder, Colorado, USA
Schlaepfer MA, Hoover C, Dodd CK Jr (2005) Challenges in evaluating the impact of the trade in amphibians and reptiles on wild populations. Bioscience 55:256-264

Schloegel LM, Picco AM, Kilpatrick AM, Davies AJ, Hyatt AD, Daszak P (2009) Magnitude of the US trade in amphibians and presence of Batrachochytrium dendrobatidis and ranavirus infection in imported North American bullfrogs (Rana catesbeiana). Biol Conserv 142:1420-1426

Schloegel LM, Ferreira CM, James TY, Hipolito M and others (2010) The North American bullfrog as a reservoir for the spread of Batrachochytrium dendrobatidis in Brazil. Anim Conserv 13(Suppl 1):53-61

Seimon TA, Seimon A, Daszak P, Halloy SRP and others (2007) Upward range extension of Andean anurans and chytridiomycosis to extreme elevations in response to tropical deglaciation. Glob Change Biol 13:288-299

Skelly DK, Bolden SR, Freidenburg LK, Friedenlands NA, Levey R (2007) Ribeiroia infection is not responsible for Vermont amphibian deformities. EcoHealth 4:156-163

Souder W (2000) A plague of frogs: the horrifying true story. Hyperion, New York, NY

Sparling DW (2003) A review of the role of contaminants in amphibian declines. In: Hoffman DJ, Rattner BA, Barton GA Jr, Cairns J Jr (eds) Handbook of ecotoxicology. Lewis Publishers, Boca Raton, FL, p 1099-1128

Stuart SN, Chanson JS, Cox NA, Young BE, Rodrigues ASL, Fischman DL, Waller RW (2004) Status and trends of amphibian declines and extinctions worldwide. Science 306:1783-1786

Teixeira RD, Periera Mello SCR, Lima dos Santos CAM (2001) The world market for frog legs. Food and Agriculture Organization of the United Nations GLOBEFISH Res Prog Rep 68 FAO, Rome, p 1-44

Thomas CD, Cameron A, Green RE, Bakkenes M and others (2004) Extinction risk from climate change. Nature 427: $145-148$

- Vredenburg VT (2004) Reversing introduced species effects: experimental removal of introduced fish leads to rapid recovery of a declining frog. Proc Natl Acad Sci USA 101:7646-7650

Wake DB, Vredenburg VT (2008) Are we in the midst of the sixth mass extinction? A view from the world of amphibians. Proc Natl Acad Sci USA 105:11466-11473

Walker SF, Bosch J, Gomez V, Garner WJT and others (2010) Factors driving pathogenicity vs. prevalence of amphibian panzootic chytridiomycosis in Iberia. Ecol Lett 13:372-382

Whitfield SM, Bell KE, Philippi T, Sasa M and others (2007) Amphibian and reptile declines over 35 years at La Selva. Proc Natl Acad Sci USA 104:8352-8356

Williams JW, Jackson ST, Kutzbach JE (2007) Projected distributions of novel and disappearing climates by $2100 \mathrm{AD}$. Proc Natl Acad Sci USA 104:5738-5742

- Woodhams DC, Alford RA, Briggs CJ, Johnson M, RollinsSmith LA (2008) Life-history trade-offs influence disease in changing environments: strategies of an amphibian pathogen. Ecology 89:1627-1639

Submitted: September 7, 2009; Accepted: November 9, 2010 Proofs received from author(s): November 12, 2010 